\title{
Development of Scoring Rubrics for IS Projects as an Assessment Tool
}

\author{
Doncho Petkov \\ Eastern Connecticut State \\ University, Willimantic, \\ CT, USA
}

petkovd@easternct.edu

\author{
Olga Petkova \\ Central Connecticut State \\ University, New Britain, \\ CT, USA
}

petkovao@ccsu.edu

\begin{abstract}
This paper describes the experience of the authors with the development of scoring rubrics for projects in the core subjects of an Information Systems program. It presents an overview of student learning assessment issues in professional courses and the role of educational projects for that purpose. Then the steps of deriving project rubrics in different subjects across the Information Systems program are shown along with some suggestions for future work.
\end{abstract}

Keywords: Project Assessment, Program Assessment, Information Systems Education

\section{Introduction}

This paper describes the process of development of scoring rubrics for projects in the core subjects in an Information Systems (IS) program. Projects are a suitable direct vehicle for assessment of student learning in professional disciplines. Assessment work in any academic program needs to be placed in the context of the broader issues related to curriculum design and continuous quality improvement (Heywood, 2000). Projects are very important teaching tools in vocational disciplines. They can be used as a way to demonstrate the technical proficiency of the students and how well they are prepared for their future profession.

According to Ewell (2002, p. 9), assessment as a term refers to the processes used to determine an individual's mastery of complex activities, generally through observed performance. It can be seen also as a special kind of program evaluation, whose purpose is to improve curricula and pedagogy. The process of assessment starts with identification of the goals and objectives for learning, understanding of how these are addressed in the curriculum, followed by data gathering and evaluation of the results to improve educational programs. Other aspects of assessment and the related terminology are discussed in Heywood (2000, pp. 16-32).

Why assessment is necessary in an IS program? The most important reason is the need to measure

Material published as part of this publication, either on-line or in print, is copyrighted by the Informing Science Institute. Permission to make digital or paper copy of part or all of these works for personal or classroom use is granted without fee provided that the copies are not made or distributed for profit or commercial advantage AND that copies 1 ) bear this notice in full and 2) give the full citation on the first page. It is permissible to abstract these works so long as credit is given. To copy in all other cases or to republish or to post on a server or to redistribute to lists requires specific permission and payment of a fee. Contact Publisher@InformingScience.org to request redistribution permission. student learning and define ways for its boosting. A by-product of this process can be an overall improvement of academic performance of the program, increase of its contribution to departmental goals and finally but not least, it can be a vehicle leading to program accreditation. Assessment is an essential part of the daily activities of academics but of- 
ten it is not appreciated enough (see Wright, 2002).

With the exception of one effort in IS program assessment at another US university (see Petkova \& Jarmoszko, 2006), the existing publications on assessment of student learning in Information Systems have focused only on single aspects of the assessment process in this discipline, like the use of surveys of graduates from a specific program (Pick \& Kim, 2000), or the role of a comprehensive exit exam conducted at national level (Reynolds, Longenecker, Landry, Pardue \& Applegate, 2004).

The purpose of this paper is to develop an approach to designing rubrics for projects in various IS subjects that can be easily adapted to the goals of a particular educational program. The need to boost the practical skills of the students and the concern for developing a mechanism to improve student learning in the IS program at the universities where the authors work were the motivations for this research. To the best knowledge of the authors, there has been no published work on issues of assessment of student learning through project rubrics within diverse subjects across an IS program.

The paper proceeds with a discussion on issues related to assessment of student learning in an academic program, followed with an exploration of the theoretical aspects of using rubrics in project assessment. A case study on the design of rubrics for projects in different IS subjects follows, which is concluded with possible directions for future research.

\section{On the Assessment of Student Learning in an IS Academic Program}

An overview of academic program assessment methods is presented in Palomba \& Banta (1999). According to them these include:

- Direct methods: exams; performance measures (demonstrating student competence in one or more skills), including oral presentations, projects, demonstrations, case studies, simulations and portfolios; juried activities with outside panels, rating student work; involvement in internships, national licensure or professional exams.

- Indirect methods: providing proxy information about student learning through questionnaires for students to reflect on what they have learned, Interviews or focus groups.

The information gathered using the above methods may be either quantitative or qualitative in nature. Initiating a relevant assessment process within an academic program requires a careful consideration of the needs of the students, as well as of the resources available for data gathering and processing of the relevant information. A valuable collection of hints on academic program assessment issues is presented in Stassen, Doherty and Poe (2002).

Course-embedded assessment has the advantages of easy implementation, cost and time effectiveness and student acceptance. Performance appraisal is the natural choice of assessment method to be used when assessing problem solving, communication and team working skills. Here we will concentrate on an issue that is not widely researched in IS program assessment literature: using scoring rubrics for the assessment of student performance in projects in IS subjects. Since such an approach provides a direct measure for student learning, it is preferred to other indirect methods for program assessment (see Palomba \& Banta, 1999), especially in a professional field like Information Systems. 


\section{Some Theoretical Issues in Project Assessment and the Use of Rubrics}

According to Heywood (2000, p. 329), a student is asked in an educational project to plan, specify, make, test and evaluate an artifact or an idea. Usually the instructor provides the students with guidelines for the structure of a project outline. Typically such guidelines, according to Heywood (2000:330), include: title; analysis of the problem; practical problems to be solved; possible solutions; resources; references; future work.

A detailed review of past research on project work is presented in Brown, Bull \& Pendleburry (1997, pp. 121-122). According to Brown et al (1997)., projects provide good, all around ability testing, potential for sampling wide range of practical, analytical and interpersonal skills, wider application of knowledge, understanding and skills to real/simulated situations, provide a measure of project and time management, a measure of team work skills and leadership. They stress the importance of monitoring project progress. According to the same authors, an instructor may choose from a wide variety of ways to assess a project: assessing artifacts; assessing the report; poster presentation/exhibition; presentations; logbooks.

It can be noted that classroom assessment for every subject in a program is left to the preferences of the individual instructor and typically includes quizzes, home assignments, exams and a team project. The selection of a particular set of methods for assessing an IS project will depend on its nature. Thus in an introductory subject on IS fundamentals it is usually the report that is assessed, while in a systems analysis or a database class, it is the design (the artifact).

Rubrics tell potential performers what elements of performance matter most and how the work to be judged will be distinguished in terms of relative quality (Wiggins, 1998, p. 153). Scoring rubrics are descriptive scoring schemes that are developed by teachers or other evaluators to guide the analysis of products or processes of students' efforts (Brookhart, 1999).

Rubrics are not checklists. They are associated with the development of criteria and rating scales for evaluation of the product against these criteria. There are two types of rubrics: holistic and analytic. According to Nitko (2001), a holistic rubric requires the teacher to score the overall process or product as a whole, without judging the component parts separately. With an analytic rubric the teacher scores separate, individual parts of the product or performance first, and then sums the individual scores to obtain a total score. The benefit of using a scoring rubric rather than weighted scores is that scoring rubrics provide a description of what is expected at each score level (Moskal \& Leydens, 2002)

According to Moskal \& Leydens (2002) whether a scoring rubric is an appropriate evaluation technique depends upon the purpose of the assessment and whether the following expected benefits are consistent with that purpose: rubrics support the examination of the extent to which the specified criteria have been reached and they provide feedback to students concerning how to improve their performance. Rubric design needs to consider the appropriateness and validity of the performance task and also the appropriateness and validity of the criteria and descriptors for discrimination in relation to the task (Wiggins, 1998, p. 164). Rubrics have been used in practice by various IS educators in the past but there is no published research on the advantages that they provide.

Apart from the descriptive role of a rubric, it has a potential for use in grading student achievement. The arithmetic calculations to obtain the corresponding percentage grade are deceptively simple but the field application of rubrics is an insufficiently researched issue in general. Mertler (2001) points out that a potentially frustrating aspect of scoring student work with rubrics is the issue of finding some way of converting them to "grades". The process of converting rubric scores to grades or categories according to him is more a process of logic and typically there are more scores at the average and above average categories than there are below average categories 
(Mertler, 2001). This issue is an open question in the theory of multiple criteria decision making and in the educational assessment literature.

\section{Criteria to Evaluate a Project}

A possible scheme for evaluation of projects according to Heywood (2000, p. 330) may include the following criteria: Planning, Execution, Originality of the design, Use of resources, Critical review or self assessment and Personal contribution. Another scheme, quoted by the same author includes: Comprehension of concepts and aims, Background information, Initiatives, Motivation/application, Appropriateness of methods and/or experimental design, Organizational skills, Competence and Independence, Ability to problem solve. A set of criteria for evaluating an experimental project is presented in Brown et al (1997). It pays attention to such dimensions as Introduction, Review, Design, Methods used, Presentation of the results, Interpretation and discussion, Conclusion drawn, Layout and referencing. With respect to an arts based project, the same authors suggest a different set of criteria: Information gathering, Structure and organization, Use of evidence, Historical analysis and argument, Presentation, Overall impression from the project. It is evident that various sets of categories might be defined depending on the nature of the project work within a specific subject.

The degree to which the content of the project is taken into account or whether the assessment focuses on process issues depends on the focus of the assessor on product or process. However, in the case of a process emphasis, it is assumed that the content would have to be correct if high scores are to be obtained (Heywood, 2000, p. 333).

A new dimension to project assessment is introduced when one needs to deal with a group effort. Such aspects are the evaluation of working together and team building, while others might be assessment of development of leadership skills and project management skills (Brown et al, 1997, p. 136).

Wiggins (1998) discusses also expectations, another important issue in assessment. According to him, it looks at the pattern of overall past performance of an individual or a group that set up the norms. Hence students can exceed norms and expectations but still not perform up to standard according to Wiggins (1998, p. 157).

What criteria need to be considered in a rubric depends on what the students should know. Without claiming that every performance needs to be assessed against all five types, Wiggins (1998, p. 168) suggests five categories of criteria to be used in rubrics, relating to the impact, the craftsmanship, the methods, the content and the sophistication of the performance. Another important distinction is between rubrics assessing generic skills or specific subject matter understanding. According to Wiggins (1998, p. 176) reliability is served by using a rubric that is unique to a task and to the samples of performance that relate to that task.

Before specifying any criteria for assessment, it is essential to define clearly the purpose of assessment, the level and type of knowledge associated with a particular task (Brualdi, 2002, p. 65). This relates to the importance of understanding the taxonomy of learning outcomes defined by Bloom (1956).

General guidelines for project scoring rubrics are suggested by Moskal \& Leydens (2002). Brualdi (2002) and Mertler (2001) provide almost similar practical guidelines for creating rubrics. According to Brualdi (2002), the steps in developing a scoring rubric are: Identify qualities for the highest score; Select analytic or holistic scoring; If analytic scoring is used, develop scoring schemes for each factor; Define criteria for the lowest level; Contrast the lowest and highest level to develop middle level; Contrast other levels for finer distinctions.

Very useful guidelines for designing rubrics can be found also in Mertler (2001). He suggests levels for a template for a holistic scoring rubric (one that does not take into account different 
criteria for the evaluation of a project): complete understanding of the problem, considerable understanding, partial, little and no understanding of the problem.

Mertler (2001) provides further an example of an analytic rubric, where for every chosen evaluation criterion is suggested the same set of four possible levels: beginning, developing, accomplished and exemplary. The next section discusses how the above concepts were applied in project assessment process in IS subjects.

\section{An Account of Defining Information Systems Project Assessment Rubrics}

\section{Definition of a Standard Set of Criteria for the Projects in Every Information Systems Subject}

The first step in creating rubrics for a group of subjects is to define a uniform set of project assessment criteria. The derived criteria for projects within the IS program at ECSU are shown in Table 1.

Table 1: Suggested project assessment criteria for subjects in an IS program

\begin{tabular}{|c|c|c|}
\hline $\begin{array}{l}\text { ECSU } \\
\text { Information Systems } \\
\text { program goals }\end{array}$ & $\begin{array}{l}\text { Corresponding litera- } \\
\text { ture findings on criteria } \\
\text { for assessment of } \\
\text { projects }\end{array}$ & $\begin{array}{l}\text { Proposed general criteria for as- } \\
\text { sessment of IS projects reflecting } \\
\text { the ECSU IS program goals }\end{array}$ \\
\hline $\begin{array}{l}\text { Technical skills (IS program } \\
\text { goal 1) }\end{array}$ & $\begin{array}{l}\text { Craftsmanship is the term } \\
\text { used by (Wiggins, 1998) }\end{array}$ & $\begin{array}{l}\text { Technical level of proficiency demon- } \\
\text { strated through application of the tech- } \\
\text { nical knowledge associated with the } \\
\text { subject. }\end{array}$ \\
\hline $\begin{array}{l}\text { Intellectual skills (IS program } \\
\text { goal 3) }\end{array}$ & $\begin{array}{l}\text { Method used, content (Wig- } \\
\text { gins, 1998) }\end{array}$ & $\begin{array}{l}\text { Problem solving skills and ability to } \\
\text { organize information, ability to com- } \\
\text { pare a problem situation against best } \\
\text { business practices or to select and jus- } \\
\text { tify the best alternative solution. }\end{array}$ \\
\hline $\begin{array}{l}\text { Interpersonal skills (IS pro- } \\
\text { gram goal 4) }\end{array}$ & $\begin{array}{l}\text { Impact (Wiggins, 1998), } \\
\text { Project management skills } \\
\text { (Brown, 1997) }\end{array}$ & $\begin{array}{l}\text { Organizational, interpersonal and time } \\
\text { management skills demonstrated in the } \\
\text { execution of the project and its recom- } \\
\text { mendations (some of it is evident from } \\
\text { the project recommendations while } \\
\text { some is evident from project logbooks } \\
\text { and team member reports). }\end{array}$ \\
\hline $\begin{array}{l}\text { Communication skills (IS } \\
\text { program goal 2) }\end{array}$ & $\begin{array}{l}\text { Sophistication of perform- } \\
\text { ance (Wiggins, 1998) }\end{array}$ & $\begin{array}{l}\text { Communication skills, demonstrated } \\
\text { through the organization of the project } \\
\text { and its presentation (sometimes it can } \\
\text { be a project walk through instead of a } \\
\text { presentation). }\end{array}$ \\
\hline
\end{tabular}

Having a standard set of project assessment criteria contributes to the faster diffusion of assessment in individual subjects. The dimensions of assessing a project within the ECSU IS program (column 3 in Table 1) were derived from the four goals of the program. They are similar to those in the standard curricular recommendations for IS programs (see Gorgone, Davis, Topi, Feinstein \& Longenecker, 2003). 
The general set of criteria for assessment of IS projects was developed partly from the existing literature on the use of projects in education (see Table 1, column 2). These were applied to the design of project rubrics for two IS subjects as is shown in Appendices 1 and 2. Further details on the design process are provided in the next sub-section.

\section{On the Design of a Project Rubric for the Introductory Informa- tion Systems Course}

Management of Business Information (BUS205) is the introductory course in the Business Information Systems major, serving also the Business program. It combines the content of the module on Personal Productivity Tools as defined in the IS2002 Curriculum Recommendations (see Gorgone et al., 2003) with some issues on Organizational IS. The small group project involves the analysis of information system implementation problems within a particular organization.

The BUS205 project description includes the following generic tasks:

1. Analyze the usage of a particular information system within a given work system. Analyze the problem within the framework provided by the work system model (see Alter, 2004); identify what potential sources of data (internal and external, including legislation, market research reports and specific research papers that may be relevant to it). Provide your assumptions characterizing the problem situation in the respective real organization for which the report is prepared.

2. Using relevant library databases provide an overview of the best relevant practices in industry regarding solutions to the problem on hand. Suggest what changes in the company information systems or its infrastructure would be needed to help provide assistance in the solution of such a problem.

3. Produce a business report that will show to the management of the organization how the problem can be effectively improved or resolved with relevant resources, including a schedule and deadlines.

Combining the above information and the content of Table 1, we derived the specific criteria to be used in the rubrics for projects in this subject:

- Ability to analyze a business and the IT in it as a work system.

- Ability to identify best business practices in the use of IT for the particular type of business and information systems.

- Ability to present the findings of the project within the report including time management issues

- Ability to provide a convincing presentation.

Following Mertler (2001), we have accepted the same four levels of distinction for student competency discussed earlier: beginning, developing, accomplished and exemplary. Thus the criteria and the grading of performance on each of them were derived on the basis of what is known about evaluation of projects in the educational literature in general and also taking into account the goals of the particular IS program and the specifics of a given subject. Appendix 1 contains the resulting rubric.

Using a similar approach, we formulated rubrics for other subjects like Systems Analysis and Design, Database Design and Security and IS Strategy. For example, the rubrics for Systems Analysis and Design (see Appendix 2) contain criteria that have the same structure and similar explanations for the levels of performance. To reflect better the nature of the content in that subject, an adjustment of the first two criteria was necessary as is shown below: 
- Ability to define user requirements of an information system and to document the analysis and design of the system.

- Ability to apply techniques for feasibility analysis, requirements analysis and Unified Modeling Language (UML) modeling in practice.

The rubrics shown in Appendices 1 and 2 were introduced in the fall of 2005 at the IS program at Eastern Connecticut State University (ECSU). A similar type of rubric for the Database Design course was introduced also the IS program at Central Connecticut State University (CCSU). The following subsection deals with the impact that rubrics may have on student learning.

\section{An Exploratory Field Experiment on the Impact of Using Rubrics in an Introductory Information Systems Course}

To illustrate the impact of using a rubric for project assessment a simple field experiment was carried out. A similar type of project on the analysis of IS implementation problems was assigned to single sections of 20 students in Management of Business Information (BUS205) during the spring and fall semesters of 2005. Both sections were taught in two sessions a week by one of the authors. The project assignments had the same goals as specified earlier in this section. The only difference in the treatment of the groups was the fact that the fall group was provided at the beginning of the semester also with the project assessment rubric shown in Appendix 1. The students in that group were urged to examine it as a guideline to the expectations towards the quality of their work while working on the project.

The spring section was divided into eight project teams. These achieved a mean percentage grade of 95.125. The fall section was split in nine teams. Those had a mean grade of $96 \%$.

The null hypothesis was that the mean percentage grade for the group not using rubrics (spring) was higher than the mean for the group that was using rubrics.

The one tail t-test for the means of two independent samples was applied. The resulting t-statistic was 1.8495444, while the critical t-value for this test corresponding to 15 degrees of freedom was 1.7530503. Since $|t|>t_{\text {crit }}$ we may conclude that the null hypothesis is rejected at the 0.05 level of confidence and that the use of rubrics has a positive impact on improving student performance.

A limitation of the above finding is the small sample and hence its exploratory nature. Further field statistical results from a larger study will be needed to support this claim.

Our preliminary experiences from using the rubrics and the qualitative analysis of student projects in this subject over three semesters demonstrate the usefulness of rubrics. They help the students focus their attention on the essential issues when working on projects. The average rating for all team projects along each criterion may serve as an indication for potential problem areas that need to be addressed by the instructor. The results could be used for deriving measures towards improvement of student learning, reaching an emphasis balance between the four types of outcomes at the various levels of the IS program and for curriculum improvement. More insights on the potential of project rubrics for the purposes of assessing student learning in individual IS subjects will be derived after processing project assessment data from several semesters.

\section{Concluding Remarks and Possible Future Work}

The suggested rubrics allow a uniform way of evaluation of projects across most subjects in an IS program. Rubrics support the standardization of the way for assessing projects in subjects with several sections like introductory level courses.

The suggested approach to designing rubrics in individual IS subjects may lay the foundation for long term assessment of student learning combining project rubrics and portfolios. Having a uni- 
form structure of the project rubrics will allow the measurement of student progress through their studies within the program. This is one of our lines for future research in this area.

Another open question is the role of an overall evaluation indicator as part of the criteria for which we have designed rubrics. A further interesting issue relates to comparing analytic and holistic rubrics.

This paper extends further the work in Jarmozsko, Petkova, \& Gendron (2003) and Petkova \& Jarmozsko (2006) towards improvement of student learning in Information Systems programs through using project artifacts as direct indicators of students' theoretical and practical skills.

\section{Acknowledgements}

The authors are very grateful for the cooperation to their departmental colleagues and to the anonymous referees for their insightful and helpful comments on improving the paper.

\section{References}

Alter, S. (2004). Making work system principles visible and usable in systems analysis and design. Proceedings of AMCIS 2004, the Americas Conference on Information Systems, New York, NY, Aug. 810, 2004, 1604-1611.

Bloom, B.S. (1956). Taxonomy of educational objectives: The classification of educational goals: Handbook I, cognitive domain. New York; Toronto: Longmans.

Brown, G., Bull, J., \& Pendleburry, M. (1997). Assessing student learning in higher education. London and New York: Routledge.

Brookhart, S. M. (1999). Teaching about communicating assessment results and grading. Educational Measurement: Issues and Practice, 18(1), 5-13.

Brualdi A. (2002). Implementing performance assessment in the classroom. In C. Boston (Ed.), Understanding scoring rubrics: A guide to teachers (pp. 1-4). Clearing House on Education and Assessment, University of Maryland.

Ewell, P.T., (2002). An emerging scholarship: a brief history of assessment. In T.W.Banta (Ed), Building a scholarship of assessment. Jossey- Bass Publishers.

Gorgone, J. T., Davis, G. B., Topi, H., Feinstein, D. L. \& Longenecker, H. E. (2003), IS 2002: model curriculum and guidelines for undergraduate degree programs in information systems, Database, 34(1).

Heywood, J. (2000). Assessment in Higher education: Student learning, teaching, programmes and institutions. Jessica Kingsley Publishers.

Jarmoszko, A., Petkova, O., \& Gendron, M. (2003).Toward assessment of information systems programs: Evaluating learning outcomes in systems analysis and design courses, Proceedings of Informing Science and Information Technology Education Joint Conference, Pori, Finland, June 2003. Retrieved October 10, 2005 from http://proceedings.informingscience.org/IS2003Proceedings/docs/166Jarmo.pdf

Mertler, C.A. (2001). Designing scoring rubrics for your classroom, Journal of Practical Assessment, Research and Evaluation, 7(25).

Moskal, B. M. \& Leydens, J. A. (2002). Scoring rubric development: Validity and reliability. In C. Boston (Ed), Understanding scoring rubrics: A guide to teachers (pp. 25-33). Clearing House on Education and Assessment, University of Maryland.

Nitko A. (2001). Educational assessment of students. Prentice Hall.

Palomba C. \& Banta T. (1999). Assessment essentials. Jossey-Bass Publishers. 
Petkova, O \& Jarmoszko, T. (2006). Assessment loop for the MIS program at Central Connecticut State University: A practice of learning, reflection and sharing. Information Systems Education Journal, $4(11)$.

Pick, J. B., \& Kim., J. (2000). Program assessment in an undergraduate information systems program: Prospects for curricular and programmatic enhancement. Proceedings of the 15th Annual Conference of the IAIM, Brisbane, Australia, 2000.

Reynolds, J.H., Longenecker Jr, H.E., Landry, J.P., Pardue J.H. \& Applegate. B. (2004). Information systems national assessment update: the results of a Beta-test of a new information systems exit exam based on the IS 2002 model curriculum. Information Systems Education Journal, 2(24).

Stassen, L.A.M., Doherty, K., \& Poe, M. (2001). Program based review and assessment: Tools and techniques for program improvement. Office of Academic Planning and Assessment, University of Massachusetts, Amherst.

Wiggins, G. (1998). Educative assessment. Designing assessments to inform and improve student performance. Jossey Bass Publishers.

Wright, B. D. (2002). Accreditation and the scholarship of assessment, in Banta T and associates. Building a scholarship of assessment, Jossey-Bass Publishers. 


\section{Appendix 1. Rubrics for Project Assessment in Management of Business Information}

The criteria that are used in this subject reflect the four general criteria for evaluation of IS projects by measuring the following learning outcomes:

1. Ability to analyze a business and its information system as a work system.

2. Ability to identify best business practices in the use of IT for the particular type of business and information systems.

3. Ability to present the findings of the project within the report including time management issues

4. Ability to provide a convincing presentation.

Hence the following rubrics were defined for the evaluation of the project report:

\begin{tabular}{|c|c|c|c|c|}
\hline \multirow[t]{2}{*}{ Criterion } & \multicolumn{4}{|c|}{ Definition of rubrics on a scale of proficiency (1-4) } \\
\hline & $\begin{array}{l}\text { Beginning } \\
\quad 1\end{array}$ & $\begin{array}{l}\text { Developing } \\
\quad 2\end{array}$ & $\underset{3}{\text { Accomplished }}$ & $\underset{4}{\text { Exemplary }}$ \\
\hline \multicolumn{5}{|l|}{ 1. Ability to analyze a business as a work system } \\
\hline 1.1. Correct application of the work system model & Inappropriate & Partial & Well-defined & Results analyzed \\
\hline 1.2. Appropriate data collection & No evidence & Secondary & Interviews & $\begin{array}{l}\text { Integrated } \\
\text { sources }\end{array}$ \\
\hline $\begin{array}{l}\text { 1.3. Are the conclusions in line with the factors for success } \\
\text { or failure of IS }\end{array}$ & No evidence & Occasional & $\begin{array}{l}\text { Good evi- } \\
\text { dence }\end{array}$ & $\begin{array}{l}\text { Evidence and } \\
\text { good analysis }\end{array}$ \\
\hline \multicolumn{5}{|l|}{ 2. Review of best business practices: } \\
\hline 2.1. To what extent is the review relevant & No sources & $\begin{array}{l}\text { Up to } 2 \\
\text { sources }\end{array}$ & $\begin{array}{l}\text { At least } 5 \\
\text { sources-no } \\
\text { justification }\end{array}$ & $\begin{array}{l}\text { Sources well } \\
\text { justified }\end{array}$ \\
\hline $\begin{array}{l}\text { 2.2. Is there evidence of critical appraisal of other work or } \\
\text { is it just descriptive }\end{array}$ & No appraisal & Occasional & $\begin{array}{l}\text { Attempted } \\
\text { minor errors }\end{array}$ & $\begin{array}{l}\text { Critical appraisa } \\
\text { no errors }\end{array}$ \\
\hline $\begin{array}{l}\text { 2.3. Is there a summary linking the review to the problem } \\
\text { on hand }\end{array}$ & No attempt & Somewhat & Attempted & Well defined \\
\hline \multicolumn{5}{|l|}{ 3. Recommendations of the project } \\
\hline $\begin{array}{l}\text { 3.1. Have the main points to emerge from the project being } \\
\text { picked up for discussion? }\end{array}$ & No evidence & Occasional & $\begin{array}{l}\text { Good evi- } \\
\text { dence }\end{array}$ & $\begin{array}{l}\text { Evidence and } \\
\text { analysis }\end{array}$ \\
\hline $\begin{array}{l}\text { 3.2. Is there a consideration on the resources needed for } \\
\text { the suggested transformation and the schedule? }\end{array}$ & No appraisal & Occasional & $\begin{array}{l}\text { Attempted } \\
\text { minor errors }\end{array}$ & $\begin{array}{l}\text { Well defined - } \\
\text { no errors }\end{array}$ \\
\hline $\begin{array}{l}\text { 3.3. Was the project developed within the time allocated } \\
\text { for the phases? }\end{array}$ & No & $\begin{array}{l}\text { Mostly on } \\
\text { time }\end{array}$ & On time & $\begin{array}{l}\text { On time and } \\
\text { with no errors }\end{array}$ \\
\hline \multicolumn{5}{|l|}{ 4. Presentation } \\
\hline 4.1. Clarity of explanation and conclusions & Lacking & Satisfactory & Good & Excellent \\
\hline 4.2. Visual impact of the presentation & No & Only text & $\begin{array}{l}\text { A plan is } \\
\text { evident }\end{array}$ & Excellent \\
\hline 4.3.Use of audio visual aids, body language & Poor & Satisfactory & Good & Excellent \\
\hline 4.4. Response to questions & Poor & Satisfactory & Good & Excellent \\
\hline
\end{tabular}




\section{Appendix 2. Rubrics for Project Assessment in Systems Analysis and Design}

The criteria used in the subject Systems Analysis and Design reflect the four general criteria for evaluation of projects by measuring the learning outcomes covered in the course and the project specific goals:

1. Ability to define user requirements of an information system and to design a system in the Unified Modeling Language (UML).

2. Ability to apply techniques for feasibility analysis, requirements analysis and UML modeling in practice.

3. Ability to present the findings of the project within the report including time management issues

4. Ability to provide a convincing presentation.

Hence the following rubrics were defined for the evaluation of the design project:

\begin{tabular}{|c|c|c|c|c|}
\hline \multirow[t]{2}{*}{ Criterion } & \multicolumn{4}{|c|}{ Definition of rubrics and scale (1-4) } \\
\hline & $\begin{array}{l}\text { Beginning } \\
1\end{array}$ & $\begin{array}{l}\text { Developing } \\
\quad 2\end{array}$ & $\underset{3}{\text { Accomplished }}$ & $\underset{4}{\text { Exemplary }}$ \\
\hline \multicolumn{5}{|l|}{$\begin{array}{l}\text { 1. Ability to define user requirements of } \\
\text { an information system and to design a } \\
\text { system }\end{array}$} \\
\hline $\begin{array}{l}\text { 1.1. Correct application of analysis and } \\
\text { design principles }\end{array}$ & Inappropriate & Partial & Well-defined & Results analyzed \\
\hline 1.2. Appropriate requirements gathering & No evidence & Secondary & Interviews & Integrated sources \\
\hline $\begin{array}{l}\text { 1.3. Is the final product relevant for a prac- } \\
\text { tical implementation of the information } \\
\text { system }\end{array}$ & No evidence & Occasional & Good evidence & $\begin{array}{l}\text { Evidence and good } \\
\text { analysis }\end{array}$ \\
\hline \multicolumn{5}{|l|}{$\begin{array}{l}\text { 2. Ability to apply feasibility analysis, } \\
\text { requirements analysis and UML model- } \\
\text { ing in practice: }\end{array}$} \\
\hline $\begin{array}{l}\text { 2.1. How are requirements assumptions } \\
\text { relevant }\end{array}$ & No sources & Up to 2 sources & $\begin{array}{l}\text { At least } 5 \\
\text { sources-no } \\
\text { justification }\end{array}$ & $\begin{array}{l}\text { Sources well justi- } \\
\text { fied }\end{array}$ \\
\hline $\begin{array}{l}\text { 2.2. Is there evidence of application of the } \\
\text { covered analysis and design principles }\end{array}$ & No appraisal & Occasional & $\begin{array}{l}\text { Attempted } \\
\text { minor errors }\end{array}$ & $\begin{array}{l}\text { Critical appraisal } \\
\text { no errors }\end{array}$ \\
\hline 2.3. Is there a evidence of knowing UML & No attempt & Somewhat & Attempted & Well defined \\
\hline \multicolumn{5}{|l|}{ 3. Project findings } \\
\hline $\begin{array}{l}\text { 3.1. Have the main points to emerge from } \\
\text { the project being picked up for discussion? }\end{array}$ & No evidence & Occasional & Good evidence & $\begin{array}{l}\text { Evidence and } \\
\text { analysis }\end{array}$ \\
\hline $\begin{array}{l}\text { 3.2. Is there a consideration on the re- } \\
\text { sources needed for the suggested system } \\
\text { and the schedule }\end{array}$ & No appraisal & Occasional & $\begin{array}{l}\text { Attempted } \\
\text { minor errors }\end{array}$ & $\begin{array}{l}\text { Well defined - } \\
\text { no errors }\end{array}$ \\
\hline $\begin{array}{l}\text { 3.3. Was the project developed within the } \\
\text { time allocated for the analysis and design } \\
\text { phases? }\end{array}$ & No & Mostly on time & On time & $\begin{array}{l}\text { On time and } \\
\text { with no errors }\end{array}$ \\
\hline \multicolumn{5}{|l|}{ 4. Presentation } \\
\hline 4.1. Clarity of explanation and conclusions & Lacking & Satisfactory & Good & Excellent \\
\hline $\begin{array}{l}\text { 4.2. Visual impact of the project walk- } \\
\text { through }\end{array}$ & No & Only text & $\begin{array}{l}\text { A plan is evi- } \\
\text { dent }\end{array}$ & Excellent \\
\hline $\begin{array}{l}\text { 4.3.Use of audio visual aids, body lan- } \\
\text { guage }\end{array}$ & Poor & Satisfactory & Good & Excellent \\
\hline 4.4. Response to questions & Poor & Satisfactory & Good & Excellent \\
\hline
\end{tabular}




\section{Biographies}

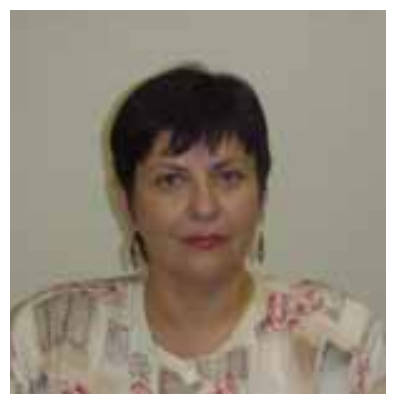

Dr Olga Petkova is an Associate Professor in MIS at Central Connecticut State University. Previously she worked at several universities in South Africa and Zimbabwe and at the Bulgarian Academy of Sciences in Sofia. Her publications are in the areas of software development productivity, systems thinking and IS education and have appeared or are accepted in Decision Support Systems, JITCA, Journal of Informatics Education Research, JITTA and elsewhere.

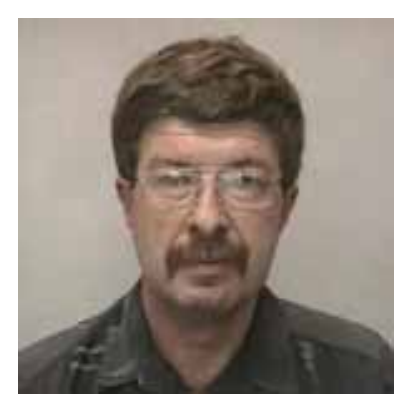

Dr. Doncho Petkov is an Associate Professor and Coordinator in BIS at the Eastern Connecticut State University. Previously he taught at the University of Natal in South Africa and in Zimbabwe. His publications in IS management, OR and Software Engineering have appeared or are accepted in the Journal of Systems and Software, DSS, Telecommunications Policy, International Journal on Technology Management, JITCA, JITTA and elsewhere. 